International Journal of Instruction e-ISSN: 1308-1470 • www.e-iji.net

Article submission code: 20201213070159

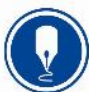

January $2022 \bullet$ Vol.15, No.1

p-ISSN: 1694-609X

pp. $55-72$

Received: $13 / 12 / 2020$

Revision: 29/05/2021
Accepted: 28/06/2021

OnlineFirst: 10/10/2021

\title{
Development of Animation Learning Media Based on Local Wisdom to Improve Student Learning Outcomes in Elementary Schools
}

\section{Bulkani}

Muhammadiyah University of Palangkaraya, Indonesia, bulkaniardiansyah@gmail.com

\author{
M. Fatchurahman \\ Muhammadiyah University of Palangkaraya, Indonesia, \\ mfatchurahman789@gmail.com
}

Harirayanto Adella

Muhammadiyah University of Palangkaraya, Indonesia, pandawaprivat@gmail.com

M. Andi Setiawan

Muhammadiyah University of Palangkaraya, Indonesia,

andisetiawan@umpalangkaraya.ac.id

Teachers play an active, creative and innovative role in online learning so that student learning outcomes get maximum results. One of the efforts made is to develop animation learning media based on local wisdom in online learning. Animation media chose because students tend to be more interested in exciting things around them. To achieve this, researchers use a research and development approach to produce a product. This research model refers to the ADDIE development model. The model trial subjects were 123 students of elementary school Muhammadiyah Palangkaraya, elementary school Panarung, elementary school Negeri Pahandut. This research produces innovative learning media animation based on local wisdom, including competencies, indicators, materials, displays, button designs, and local potentials of Indonesian Kalimantan. The four elementary schools' effectiveness trials showed that the mean scores were post-test (81.02) and pre-test (54.82). So it can be said that the designed model is effective in improving learning outcomes.

Keywords: animation learning media, local wisdom, student learning, media, teaching

\section{INTRODUCTION}

The educational process in Indonesia produces human resources who have cognitive, affective, and psychomotor abilities. Education facilitates students to develop themselves to be even better (Wiyarsi, 2020). Education in Indonesia has several levels of education, one of which is the primary school level. At the primary school level, the principles taught are basic. Therefore, at the stage of primary school education, it will

Citation: Bulkani., Fatchurahman, M., Adella, H., \& Setiawan, M. A. (2022). Development of animation learning media based on local wisdom to improve student learning outcomes in elementary schools. International Journal of Instruction, 15(1), 55-72. https://doi.org/10.29333/iji.2022.1514a 
significantly affect children's development. By looking at the changing times and current technological advances, education in Indonesia, especially elementary school teachers, must be innovative and creative using technology to improve students' quality (Hanif, 2020; Sarioğlu \& GIrgIn, 2020). The education process is carryout by implementing the curriculum so that learning runs systematically. The education process creates a knowledge transfer process that will encourage students to carry out the learning process (Fujiawati, 2016). Individuals can become qualified because of the quality education system (Atsani, Rohmatun et al., 2020). The primary purpose of learning is to make students independent, understand social life, and organize themselves using effective means and quality education. One of the subjects in the elementary school curriculum is mathematics. Some students consider that Mathematics is frightening because it requires a high enough understanding of reasoning, logic, and calculation rules that must be understood.

Mathematics learning at the elementary school level emphasizes understanding basic mathematics concepts and shows symbols (Nasir, 2018). Conveying mathematical concepts requires strategies, techniques, methods, and media to understand mathematics more efficiently. In addition to facilitating understanding, the use of practices, procedures, and media can make the learning process of mathematics more enjoyable. Learning mathematics is no longer a scourge of learning that is feared and even avoided by students. With current developments in technology and information, mathematics learning should be more creative, innovative, and fun so that learning outcomes and student learning achievements become better or increase (Aishah et al., 2020). Students' tendency to prefer to learn to use learning media such as the internet, animation, and video makes it easier for them to understand mathematical concepts because mathematical ideas are prominent. The production of mathematical concepts is crucial because when the idea conveyed is wrong; it will make student reasoning or student logic wrong or wrong and vice versa. If the idea expressed is correct, then the student's reasoning or logic becomes correct, so that students easily develop into the next mathematical material.

The phenomenon in primary schools is that many students ignore the teacher's explanation of mathematics's teaching and learning processes. Students prefer to play with their friends; students have difficulty understanding the subject matter. From the weekly learning results obtained from the teacher, there were still many students who did not complete it. This phenomenon shows that mathematics learning is still not optimal. This condition can be due to the lack of strategies, techniques, methods, models, and media in the learning process. Exposure from the school, namely the principal and vice-principal in the field of curriculum, explains that teachers are still lacking in utilizing multimedia-based learning media. Most of the teaching teachers use books and pictures that cause mathematical concepts to be insufficient to support the mathematics learning process. Seeing this condition, the teacher needs to develop information technology skills by making animation media in learning.

Mathematics is learning that presents abstract learning to be concrete. Therefore it is necessary to have learning media that can provide approval and come up with ideas. By 
conveying clear ideas through the media, students get clear reinforcement or support in understanding these abstract concepts. Media as a means to share information (Tafonao, 2018). Media is a variety of objects, people, and the environment used to create conditions for information recipients to obtain information (Azhar, 2017). The media used in learning varies significantly according to the characteristics of these subjects. One of the interactive learning media is animation (Ngurah et al., 2020). The advantages of animation learning media are that they have an attractive appearance in moving images that can be combined with sound and can be operated independently by students to have an exciting and enjoyable experience (Alsubaie \& Alabbad, 2020; Handayani \& Ahmadi, 2020). Animated media for students is exciting and fun (Fatmawati et al., 2020). Besides, abstract concepts in mathematics learning are easy to present, display, and convey when using animation learning media.

The facts show that the teacher's skills in making animation are still lacking; the teacher rarely creates and applies various learning media. The reason is the lack of teacher skills in mastering technology. Creating or designing animation learning media requires skills in both design concepts and animation-making skills. Teachers should continually hone and improve their skills following technological advances (Aydın \& Onsekiz, 2020). Learning media that take advantage of advances in information technology is one form of practical online learning (Andini \& Supriadi, 2018; Yusuf et al., 2018). Media facilitates teachers so that they can design a better education. The animation will explain students from a more exciting perspective (Fauzy \& Revita, 2020).

They made animation learning media use various software (software) operated via a computer, laptop, or android. Much available software products for creating or designing animation and one of this software is Macromedia flash. In Macromedia, flash software provides various features to design or build animation (Utomo et al., 2020). Macromedia flash is easy to use, and there are many tutorials for making animation in the form of books, modules, and videos. Macromedia Flash is an application operated using a computer; this application can present abstract concepts into the concrete through animated audiovisual displays.

\section{METHOD}

\section{Research Design and Flow}

This study uses research and development design. This design will produce innovation (Nainggolan et al., 2020; Şılbır et al., 2020). In this research, innovation is creating a learning animation media that can help students in the learning process achieve maximum learning outcomes. The design used is the ADDIE model with the stages of analysis, design, development, implementation, and evaluation (Sofyan et al., 2020). The following are the stages of the ADDIE model development research:

1. The analysis. The researcher digs up data about the actual conditions related to learning facilities, teachers, students, and the ongoing learning process. The observations from the description show that: The curriculum used in schools is the 2013 curriculum. Based on the observations' results, the studied mathematical material is related to the perimeter and area of a square, long square, and triangle. 
The learning media used by the teacher during the observation were books and pictures. Researchers found that many students played and chatted during the teaching and learning process. The learning outcomes of many students are still below the average value of learning completeness.

2. Design. Researchers found a unique mathematics learning design model as a solution to the problem analysis. Mathematics requires reasoning and logic for abstract concepts. The animation will help make it easier to understand abstract concepts to be concrete. Furthermore, the researcher designed and presented a flat shape with its simulation to explain/show conceptual material with animation.

3. Development. After going through the design stage, the researcher then enters the development process. This developer's step is designing the model systematically as needed (Arslan et al., 2020). At the development stage, animation learning media is still in prototype form and cannot test because it has not received validation from media and field experts. The development carried out by researchers is to create a learning media model based on local wisdom using Macromedia flash software.

4. Implementation: The model implementation stage carries out in three schools that the researcher had determined. The first stage carries out; namely, the researcher conducts a pre-test to assess learning outcomes before the animation learning media implement. The next step is the implementation of animation media development in learning. The last is the post-test to measure after the performance of the model in learning.

5. Evaluation: The evaluation stage is carried out based on the media implementation results in the learning process. The assessment carries out based on the products. The assessment is carried out based on the students' pre-test and post-test results obtained from measurements before and after.

\section{Population and Sample}

This study's population was all students at Muhammadiyah elementary school Palangkaraya with 308 students, 239 students at Pahandut Public Elementary School, 355 students from Panarung Public School, and 902 total population. As for the number of research samples, 123 students divide as follows.

Table 1

Research sample

\begin{tabular}{|c|c|c|c|}
\hline No & School & Class & Sample \\
\hline \multirow{2}{*}{1} & \multirow{2}{*}{ Muhammadiyah Palangkaraya Elementary School } & IVa & 20 \\
\hline & & $\mathrm{IVb}$ & 21 \\
\hline \multirow{2}{*}{2} & \multirow{2}{*}{ Pahandut State Elementary School } & $\mathrm{IVa}$ & 22 \\
\hline & & IVb & 19 \\
\hline \multirow[t]{2}{*}{3} & \multirow{2}{*}{ Panarung State Elementary School } & $\mathrm{IVa}$ & 20 \\
\hline & & $\mathrm{IVb}$ & 21 \\
\hline \multicolumn{2}{|c|}{ TOTAL } & & 123 \\
\hline
\end{tabular}


The sample selection is basing on the same class and level in each existing primary school. Sample selection using strata random sampling intends to maintain the quality of existing research data.

\section{Instrument}

The data collection instruments used were observation, validation sheets, FGD sheets, and tests. The test used is the choice of mathematics subjects. This multiple-choice test uses to measure mathematics learning outcomes before and after the model is implemented. Statements use to collect data on the state of the school and problems that occur at school. The validation sheet intends to assess the model's suitability with the field's needs to adjust to its needs. Expert and practitioner validation sheets also prepare to know the model's feasibility from aspects, namely, the objectives, rationale, function, and role of the model to find out future improvements. FGDs conduct to test the feasibility of the models compiled by researchers. The components of the model in the FGD and subjected to validation tests were part of the essential competencies, indicators, materials, design of displays and buttons, and local potential in Indonesian Kalimantan. The research test here is a multiple choice to measure students' learning outcomes before and after treatment using animation learning media

\section{Data Analysis Technique}

Learning media is considered feasible by being analyzed from the model validation analysis results and the FGD carries out. Validation is analyzed descriptively to better describe the model after getting input from experts and practitioners in the field. Quantitative data analysis was obtained from multiple-choice test results and was used to determine learning outcomes between before and after receiving treatment (Reilly, 2020). The multiple-choice instrument consists of 11 multiple-choice items. Research is said to have standard data or not by conducting normality tests and homogeneity tests to see whether the research sample is homogeneous or not

\section{FINDINGS}

\section{Results of the Development of Animation Learning Media}

This research will produce a model by applying the ADDIE model as follows

Analysis

Curriculum analysis, based on observations made, the curriculum applied in elementary schools in the 2013 curriculum. The 2013 curriculum is thematic; wherein there are several subjects at the time of observation in grade IV. The theme studied is theme 4, namely various jobs, sub-themes 1, namely the types of work, and enter into learning 2 . Some necessary competencies and indicators must achieve in learning. Material Analysis, based on observations, the learn being studied in mathematics. The field analysis results show that the need for a model in the field is related to subjects, particularly on the flat shape material. 


\section{Design}

This design stage is base on the results of the analysis conducted by the researcher. From the results of the research, the researcher designed a model. The model includes necessary competencies, indicators, materials needed for flat buildings, display design, interactive button design, back sound, and additional local potential in the form of other knowledge about the local potential in Central Kalimantan. The model design is as follows:

Table 2

\section{Design model}

\begin{tabular}{|c|c|}
\hline $\begin{array}{l}\text { Intro } \\
\text { (Opening/Initial } \\
\text { Display) }\end{array}$ & $\begin{array}{l}\text { This display will present in animation, learning media titles, interactive buttons to go to the } \\
\text { following menu, and back sound (background music). This display has a function as a } \\
\text { media opening display. It has increased student enthusiasm by displaying an attractive } \\
\text { animation and back sound to improve student enthusiasm for learning. This intro display } \\
\text { has an essential role because it is the first impression witnessed by students; therefore, the } \\
\text { intro's appearance is made as attractive as possible to create a pleasant image to stimulate } \\
\text { students to follow the subject matter }\end{array}$ \\
\hline Menu 1 & $\begin{array}{l}\text { In this display, there is an animation of a child who will become a "friend" during learning } \\
\text { media. At this stage, the child's energy introduces himself; then he explains the media's } \\
\text { function, namely, learning about flat shapes and giving the enthusiasm to participate in } \\
\text { learning. In this view, several interactive buttons have tasks according to their button } \\
\text { names. When the button is pressed/clicked, it will display the material according to the } \\
\text { button name. The buttons on this display are the necessary competency buttons and } \\
\text { indicators, the square area button, the rectangular area, the triangle area, and the shape's } \\
\text { perimeter. In this display, there is also a back sound in the form of musical instruments }\end{array}$ \\
\hline Menu 2 & $\begin{array}{l}\text { This display is slightly different from the previous menu display because of additional local } \\
\text { potential buttons and practice questions buttons. This local wisdom button functions as } \\
\text { other knowledge about local potential, especially the local potential of Central Kalimantan } \\
\text { in knowledge about hornbills. This local potential included gaining an understanding of } \\
\text { local wisdom found in Central Kalimantan. Besides, another function is as an interest to } \\
\text { provide entertainment in the learning process }\end{array}$ \\
\hline $\begin{array}{l}\text { Basic } \\
\text { competencies } \\
\text { and indicators }\end{array}$ & $\begin{array}{l}\text { The flat-shaped subject matter's essential competencies and indicators to be achieved in } \\
\text { learning will display in this display. This display's function is to determine the learning } \\
\text { objectives to conduct to become directed and systematic. In this display, there are several } \\
\text { buttons, namely the home button and volume }\end{array}$ \\
\hline Square area & $\begin{array}{l}\text { In this square area view, an illustration of the problem related to the square will present. } \\
\text { After seeing the problem's description, students will invite to find a way to solve the } \\
\text { problem. There is a simulation button; this button shows the stages/process of solving a } \\
\text { square area's issues. }\end{array}$ \\
\hline $\begin{array}{l}\text { Square area } \\
\text { simulation }\end{array}$ & $\begin{array}{l}\text { The display in this square area simulation is the stage of solving the square area's problems. } \\
\text { The concept of finding a formula for the area square with the help of animation will present } \\
\text { so easily understood by students. In this view, there is a back sound in the form of a sape' } \\
\text { instrument (a traditional eastern Kalimantan musical instrument). Besides, there is an } \\
\text { interactive button, namely the home button, which functions towards menu } 2 \text {, then the } \\
\text { following button to continue the next stage; otherwise, the back button repeats the previous } \\
\text { step }\end{array}$ \\
\hline $\begin{array}{l}\text { Rectangular } \\
\text { area }\end{array}$ & $\begin{array}{l}\text { In the rectangular area view, an illustration of the problems related to the rectangle will } \\
\text { present. Furthermore, after the students watched the description, the students were invited } \\
\text { to solve the problem. In this display, a simulation button functions to display a simulation } \\
\text { of solving research problems. }\end{array}$ \\
\hline $\begin{array}{l}\text { Rectangular } \\
\text { simulation }\end{array}$ & $\begin{array}{l}\text { The display in the rectangular area simulation is the stage/process of solving the rectangle } \\
\text { area's problems. In this view, the concept of finding a formula for area rectangle will be } \\
\text { presented with the help of animation so that the idea can be witnessed and easily }\end{array}$ \\
\hline
\end{tabular}




\begin{tabular}{|c|c|}
\hline & $\begin{array}{l}\text { understood by students. The process of finding the formula is carryout in stages. In this } \\
\text { view, there is a back sound in the form of a 'sape' instrument (a traditional eastern } \\
\text { Kalimantan musical instrument). There is also an interactive button on this display, namely } \\
\text { the home button, which functions towards menu } 2 \text {. The next button is to continue the next } \\
\text { stage; otherwise, the back button repeats the previous step. }\end{array}$ \\
\hline $\begin{array}{l}\text { The area of the } \\
\text { triangle }\end{array}$ & $\begin{array}{l}\text { The view triangle area is almost the same as the previous view of the square and the } \\
\text { rectangle area. Still, the difference is that an illustration of problems related to the triangle } \\
\text { will present in this view. Furthermore, after the students watched the example, the students } \\
\text { were invited to solve the problem. In this display, a simulation button functions to display } \\
\text { simulated problem solving related to the triangle area. }\end{array}$ \\
\hline $\begin{array}{l}\text { Triangle } \\
\text { simulation }\end{array}$ & $\begin{array}{l}\text { The display in the simulation of a triangle area is the stage/process of solving a triangle area } \\
\text { problem. In this view, finding a triangle with animation will be presented as a concept that } \\
\text { students can easily witness and easily understand. The process of finding the formula is } \\
\text { carryout in stages. In this view, there is a back sound in the form of a 'sape' instrument (a } \\
\text { traditional eastern Kalimantan musical instrument). There is also an interactive button on } \\
\text { this display, namely the home button, which functions towards menu } 2 \text {. The next button is } \\
\text { to continue the next stage; otherwise, the back button will repeat the previous step }\end{array}$ \\
\hline $\begin{array}{l}\text { Surround a flat } \\
\text { shape }\end{array}$ & $\begin{array}{l}\text { Furthermore, there is an illustration of the problem regarding the shape's perimeter in the } \\
\text { perimeter view. Then students will be invited to solve the problem by finding the formula } \\
\text { for the frame of a flat body. There is a simulation button on this display, wherein the } \\
\text { simulation shows an animation displaying the circumference concept. After watching the } \\
\text { traveling concept animation, the following button functions to explain the idea again to } \\
\text { conclude traveling }\end{array}$ \\
\hline Exercises & $\begin{array}{l}\text { In this view, we will also discuss how to solve these problems in stages. In this display, a } \\
\text { home button functions to go to menu } 2 \text {, the following button to go to the next step, and a } \\
\text { back button to repeat the previous stage }\end{array}$ \\
\hline Local wisdom & $\begin{array}{l}\text { In this display of local potential, knowledge of local wisdom found in Central Kalimantan } \\
\text { will be presented, especially about hornbills; here, a video and a brief explanation of } \\
\text { hornbills will show. This display serves to increase students' insight into local wisdom and } \\
\text { intervention in the learning process to make learning more enjoyable. Besides that, the } \\
\text { rhythm of the essential music in this model also uses typical Dayak music }\end{array}$ \\
\hline
\end{tabular}

\section{Development}

After carrying out the design process, they are then entering the development stage, namely making a model based on the design results. In this process, the researcher collected several components needed for the development stage. These components are as follows:

A laptop is a device in the form of a mini-computer that can carry anywhere. Macromedia flash software, which is software that is installed (installed) on a laptop. Images, namely images collected, were created and designed by researchers to develop animations, backgrounds, and interactive buttons-Backsound (background music) manages several musical instruments, especially;'sape musical instruments. The 'sape' instrument is a musical instrument that plays with traditional tools from East Kalimantan. The purpose of selecting 'sape' musical instruments is to raise local wisdom and relaxation music during the learning process - sound effects, unique sounds that will later use as button sound effects. Then there are the sound effects used by researchers as children's animated voice actors. Text, namely, creating, arranging, and designing text, words, and sentences in the model. 
Furthermore, the modeling stage uses Macromedia flash software. In making this, the researcher creates a model tailored to the design of that design. Researchers make several flash files; flash files are product files produced by Macromedia flash when a product has been finished or stored; in these products, there can be animations, images, text, sound, and a combination of them. In the modeling stage, there several techniques made by researchers, such as load movies, namely moving from one flash to another using an action script that installs/programmed on a specific button. Besides, there is also a frame by frame technique, which moves from one frame to a flash file.

After the model finish, the next step is the validation process and the model's front group discussion. Validation carries out to determine the feasibility of the model. The validation process was carryout by researchers involving 8 class teachers and two media experts. The results of the model validation are as follows:

Table 3

Validation results of the animation learning media model

\begin{tabular}{|c|c|c|c|}
\hline Name & Score & Assessment & Repair \\
\hline $\begin{array}{l}\text { Dedy Setyawan, } \\
\text { M.Pd }\end{array}$ & 71 & Very good & $\begin{array}{l}\text { Reduce the use of colours that are too varied in the } \\
\text { background }\end{array}$ \\
\hline $\begin{array}{l}\text { Dr. Chandra } \\
\text { Anugerah P., } \\
\text { S.Kom }\end{array}$ & 68 & Very good & $\begin{array}{l}\text { Improve the appearance of the intro to make it more attractive. } \\
\text { Change the background colour of the writing column }\end{array}$ \\
\hline Monika, S.Pd & 56 & good & $\begin{array}{l}\text { This model can use because it can increase student motivation } \\
\text { in learning }\end{array}$ \\
\hline $\begin{array}{l}\text { Utami Indah } \\
\text { Paskawati, S.Pd }\end{array}$ & 52 & good & $\begin{array}{l}\text { This model is good because it can help students' ability to } \\
\text { understand flat shape material. This model is better introduced } \\
\text { to schools to increase teachers' insight into learning strategies }\end{array}$ \\
\hline $\begin{array}{l}\text { Letha Luber, } \\
\text { S.Pd }\end{array}$ & 71 & Very good & $\begin{array}{l}\text { Pay attention to the school's facilities and infrastructure in } \\
\text { applying this model, improvements to words and sentences in } \\
\text { the model. }\end{array}$ \\
\hline Nurminah, S.Pd & 56 & good & $\begin{array}{l}\text { This model needs to be socialized to educators to broaden the } \\
\text { educators' insight. }\end{array}$ \\
\hline $\begin{array}{l}\text { Linda Panjaitan, } \\
\text { S.Pd }\end{array}$ & 54 & good & $\begin{array}{l}\text { This model is excellent; it is necessary to pay attention to its } \\
\text { facilities and infrastructure in its application. }\end{array}$ \\
\hline Masrawan, S.Pd & 64 & good & $\begin{array}{l}\text { This model is in a suitable category because learning will be } \\
\text { more fun for students. }\end{array}$ \\
\hline $\begin{array}{l}\text { Adhyaksi Waty, } \\
\text { S.Pd }\end{array}$ & 64 & good & $\begin{array}{l}\text { This model is exciting and can make the learning atmosphere } \\
\text { more interactive }\end{array}$ \\
\hline $\begin{array}{l}\text { Ulia Ulfah, } \\
\text { S.Pd }\end{array}$ & 67 & Very good & $\begin{array}{l}\text { In its application, it is necessary to pay attention to school } \\
\text { facilities and infrastructure. }\end{array}$ \\
\hline Total & 623 & Average 62,3 & \\
\hline
\end{tabular}

After calculating the model validator's average score, the validator's mean score was 62.3. It can conclude that the learning media model is in a suitable category but requires a little improvement before it uses following the comments, suggestions, and gains from the validator. For this reason, a front group discussion also held related to the model development; from the results of the front group discussion with ten practitioners, some improvements obtain. The results of the FGD with several practitioners showed an improvement in terms of appearance, namely, the use of colour must be able to steer clear contrasts so that it is easy to read for students. After improving the developed 
model, developing an animation model based on local wisdom is created. This last model consists of several components; the following is the final model component for the animation based on local wisdom.

Table 4

Development model of animation learning media

\begin{tabular}{l} 
Initial model \\
\hline Initial view \\
In this model, the initial display is a \\
learning equipment and the animation \\
media title. This display will display for \\
about 5 seconds, then immediately \\
switches to the menu display
\end{tabular}

switches to the menu display

automatically.

Menu display

Development model

In the menu display, the introductory

part shown in the form picture batik Initial view

In this developed model, the initial appearance is in the form of a study table background, study equipment, a title, and an additional animation of a flat shape that can change from a square, a triangle, and a circle. In this view, there is a development in adding a back sound or background music. In this view, an additional development form start button functions as a button to go to the menu

cloth with some questions regarding the observation results of the batik image Menu display

In this display, an animation will show, namely a child who introduces the animation media related to the material to teach. View perimeter of the rectangle This view presents a question about a rectangular image. The image that is displayed is an animated line that forms a rectangular shape. Then after watching the animation, students are invited to calculate the circumference of the rectangle

\section{Rectangular area view} In this view, you will immediately present how to calculate the area of a rectangle. This view also showed an animation in a rectangular image divided into small columns that ultimately divide the rectangle. Students are invited to count all the small columns that divide the rectangle.

View perimeter of the rectangle

In the developed model view, discussing a flat shape's circumference will first present a problem and calculate a perimeter. There is a simulation button function to go material will discuss how to calculate the rim. In this display, an animation of a person cycling around a soccer field in a rectangular shape will present; then, students invite to calculate how much distance to go around the soccer field for one round. In this view, students expect to understand the concept of roving.

Rectangular area view

In the model developed when entering the material area, a problem related to a rectangle area related to everyday life will present. In this display, a simulation button serves to illustrate discussion material regarding solving the rectangle's problems.

In this view, an explanation rectangle is presented, what is meant by the rectangle's width and length. There is also a next button that functions to the next display, and the back button functions to the previous show. If we click the following button, it will display a discussion on how to calculate a rectangle area, as below.

In this view, a discussion calculates the rectangle area present to find the formula for a rectangle's space. In this display, background music adds in a sape instrument (a Dayak tribal musical instrument), which can be adjusted to a large or small volume, aiming to make the learning process less tense. The next development is material, namely material regarding a square area, as below:

The material developed next is about a triangle area.

\section{Exercise view} Exercise view

In this exercise view, there are several practice questions. The type of item is a form; students invite to choose one of the answers, then put the answer in the question column provided, then click check to see the results.
In the developed model, there are exercises. In this part of the activity, students invite to solve some of the questions and discuss them. 
Some of the developments in this study are to display the initial media model. Internet access requires hardware, for example, a laptop or an Android cellphone, then open the Ministry of Education and Culture's learning resource site or website, then look for mobile media titles and rectangular areas for grade 4 Elementary school semester 2. After being developed, if they want to use the media, they do not need internet access; users only need files that have been saved on a laptop or android phone and then open/run. In the initial model, the way of presenting material without going through the contextual approach to students 'daily activities, but in the developed model, there is a contextual approach process in the form of problems that often occur in students' daily lives. Besides that, at the discussion/simulation stage in the developed model, the process is presented. Sequential and gradual. The model developed by the media is increasingly attractive with the addition of sound. Sound effects on buttons and background music and various forms of animation and additional knowledge in local wisdom knowledge such as Sape instrument music and video hornbills are different from the initial model, which tends to silent (without sound). The addition of these components to the model that has been compile can provide added value in the form of uniqueness according to the right local culture to add new understanding to students.

\section{Implementation}

Furthermore, after improving the model, the model becomes a final model ready to be tested, limited to class IV. In the trial process, the researchers used the pre-experimental pre-test and post-test one-group design methods. Before conducting the test in class IV, the researcher validated the items, namely looking for valid questions by validating the items. After doing calculations with the SPSS application's help, the researcher found 11 right questions from the 20 things whose validity had sought. During the implementation, the researcher presented the material using animation media. Presentation of flat shape material is carried out in stages starting from conveying essential competencies and learning indicators. Every discussion will always start by presenting a square, rectangle, triangle, and shape perimeter. After submitting the problem, a simulation will give, namely a depiction of a system or process in solving the problems that occur, so that it will produce a conclusion in the form of formulas in determining the area of a square, rectangle, triangle, and perimeter of the shape.

\section{Evaluation}

The final stage is the trial results evaluation process to determine the effectiveness of animation learning media carried out by researchers in class IV. This study's initial animation model is a circumference and rectangular area of the animation learning media model for grade 4 semester two elementary school students on the Ministry of Education and Culture's learning resources website. The reliability level of the Cronbach Alpa Based value is 0.718 , which means it has high reliability. Furthermore, after getting the pre-test result data, the researcher conducted a normality test. Kolmogorov Smirnov normality test results obtained significance $(\mathrm{Sig})$ of $0.086>0.050$; thus, pre-test data distribution normal. Researchers used the Kolmogorov Smirnov test for the posttest normality test, a normality test often used for large samples and small sample sizes. According to Kolmogorov Smirnov, the normality test results show Sig (significance) 
value was $0.61>0.050$. Thus, it can conclude that the distribution of post-test data normally distributed. The following is a graph of the calculation of the analysis of the pre-test and post-test scores in the development of an animation learning media model based on local wisdom on the flat shape material in class IV.

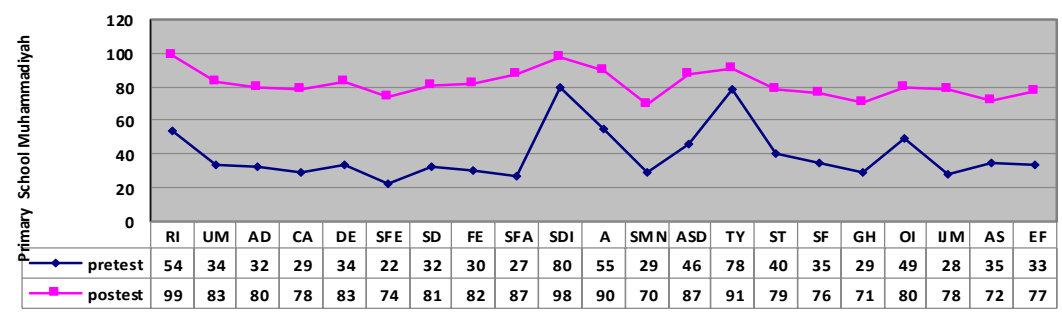

Figure 1

The score of student learning outcomes of class IVa Muhammadiyah Elementary Schools

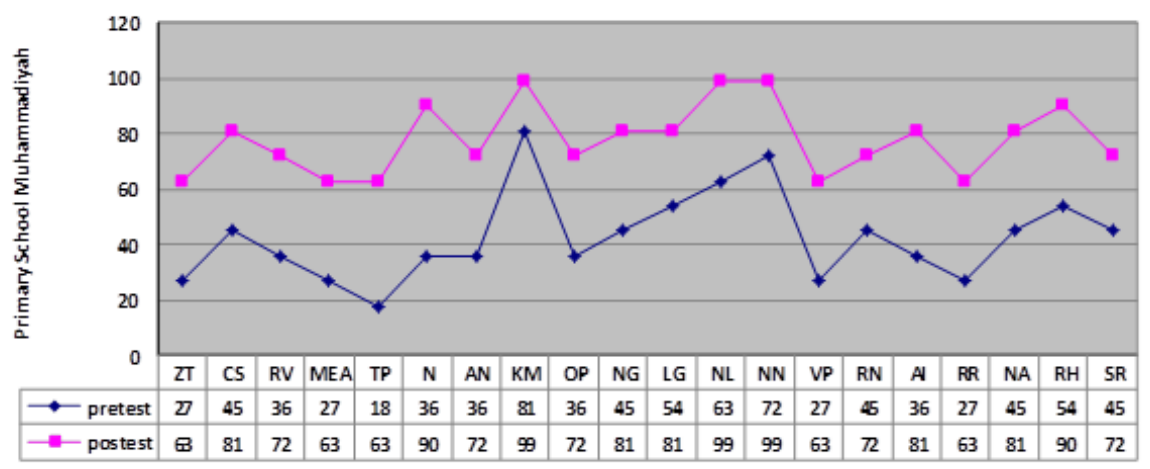

Figure 2

The score of student learning outcomes of class IVb Muhammadiyah Elementary Schools 


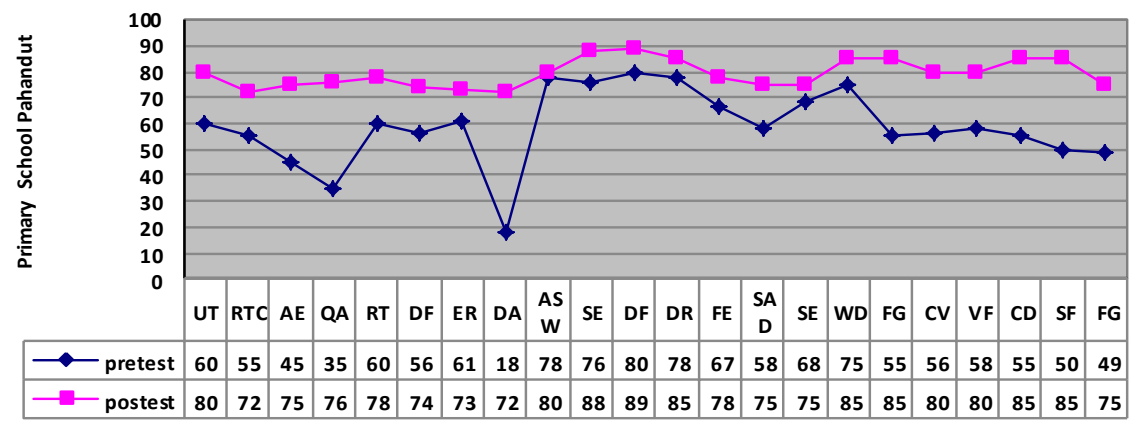

Figure 3

The score of student learning outcomes of class IVa Elementary Schools Panandut

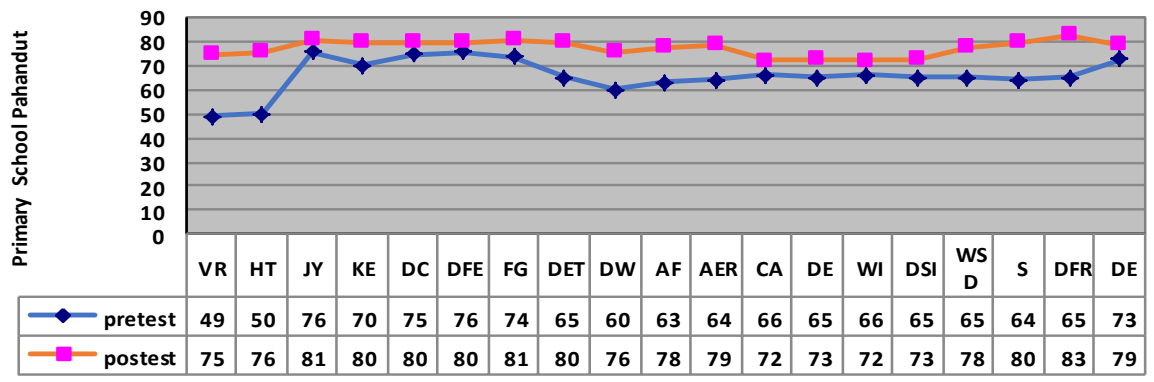

Figure 4

The score of student learning outcomes of class IVb Elementary Schools Panandut

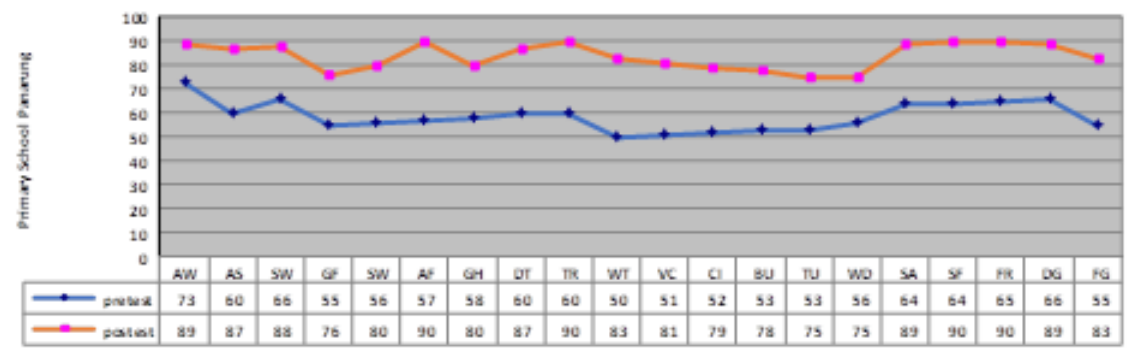

Figure 5

The score of student learning outcomes of class IVa Elementary Schools Panarung 


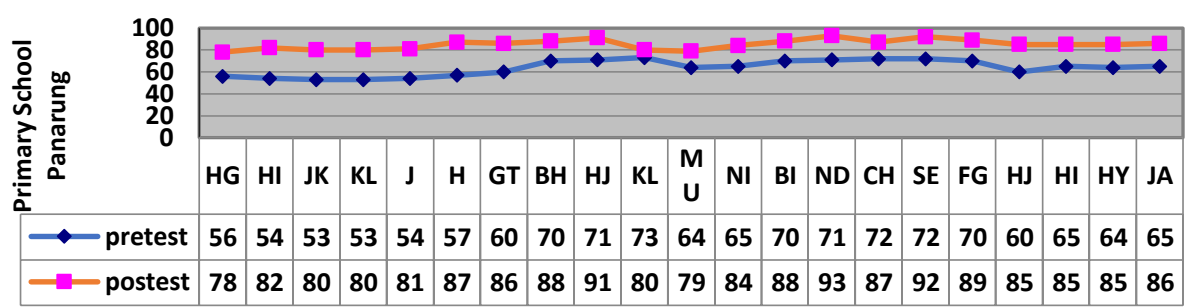

Figure 6

The score of student learning outcomes of class IVb Elementary Schools Panarung

\section{Hypothesis test}

Paired sample t-test aims to determine whether there is a difference in the mean of the two paired samples. The sample that will test for the hypothesis is students' learning outcomes using animation learning media based on local wisdom. The T-test analysis results showed a difference in the mean score between before (54.82) and after (81.02). The analysis results show that the correlation between the sample t-test is 0.557 , with a significant level of 0.000 . The result of the t-test calculation is Sig. 2-tailed $0.000<\propto=$ $5 \%$ or 0.050 , it can be concluded that there is a significant difference between students 'mathematics learning outcomes at the pre-test before using animation learning media and the students' post-test results after using animation learning media, so hypothesis Ha is accepted

\section{DISCUSSION}

As one of the countries affected by Covid-19, Indonesia must adjust to the new normal conditions to carry out all activities correctly. The education sector is one of the fields that must be able to adapt to these conditions. Education plays a role in developing literacy, scientific methods, scientific concepts, and science (Dewi et al., 2019). As part of education, teachers try to adapt to new conditions during the covid-19 period. These efforts can be implementing innovative and creative learning that emphasizes aspects of information technology (Leasa et al., 2020). Advances in information technology currently positively impact education developments (Neta et al., 2020). Efforts that can do are designing innovative learning media in animation based on local wisdom. This learning media will help students make it easier to capture the contents of the lessons delivered by the teacher (Haviz et al., 2020). Animated learning media will train students to achieve learning goals by creating innovative products. The learning media developed emphasizes animation and local wisdom as part of learning. The animation chose because it saw students who had high imagination and curiosity during elementary school age. Students' curiosity is also great with the development of this learning media; it will increase interest and learning outcomes to achieve satisfactory results. The researchers conducted development research with the ADDIE model to produce this media, which consisted of the analysis, design, development, implementation, and evaluation stages. 
The resulting development results are in the form of animation learning media based on local wisdom. The research findings bases on conditions in the field. The conditions that exist in some schools are still not finding animation models in mathematics learning. Teachers tend not to produce interesting learning for students, while students' needs need something interesting to support so that learning outcomes can be even better. Previous research suggests that one of the determinants of education quality is innovative teachers (Suratno et al., 2020). Another basis for developing animated models in mathematics is also because mathematics is a subject that students have not been interested in school. These conditions underlie the creation of this animation learning media model. This model has the advantage of increasing students' interest in learning because the model's content contains interesting things for students.

Another advantage of this model is that it also carries local wisdom to understand students' learning processes. Previous research supports this model, which says that animation is a popular thing (April \& April 2020). The animation is a part of multimedia, which is very popular in the digital era (Sukmana, 2018). The animation is one of the most useful media in various fields (Amri et al., 2020). on the other hand, this model also has a weakness, namely because it carries local beauty, so that it will be difficult to apply it to students with different cultural backgrounds. This model can only implement in mathematics learning.

The flow of developing animated learning media based on local wisdom starts with curriculum analysis, analysis of the subject matter, analysis of learning media, analysis of the learning process, analysis of learning media, and analysis of learning outcomes. The second stage is designing and conceptualizing a learning media based on the results of the investigation. The development stage is collecting the necessary components and making animation learning media using Macromedia flash software. After making the media, the media is tested for its feasibility by the validator to obtain a final model in animation learning media ready to be tested. The next stage is a product trial or implementation. The results of the Macromedia flash animation learning media's effectiveness test on the flat shape material in class IV are said to be effective. The paired sample t-test results on the pre-test and post-test results show the sig value of the paired-sample t-test, $0.000<\propto=5 \%$, or 0.050 .

The teacher made innovative learning media innovations to solve learning problems during the Covid-19 pandemic. Learning media is an intermediary or introduction to messages from senders to recipients (Siburian et al., 2020). The treatment results prove that animation learning media based on local wisdom contributes to learning mathematics. Students have a better interest in learning, and academic achievement has experienced significant changes for the better. The teacher becomes very helpful with this media's existence so that the teacher does not have to explain verbally to students. However, the results of this development are only limited to mathematics subjects in building materials. There is still much need for development in other materials so that learning during the Covid-19 pandemic can get good results. 


\section{CONCLUSIONS}

The results showed that the resulting model made a positive contribution. The resulting model can help teachers to create a more interesting learning process and improve student learning outcomes. The development model contains an intro, menu, basic competencies and indicators, simulations, practice questions, and local wisdom. The model effectiveness test shows that the service model uses in the teacher's learning process. The data analysis results before and after the model was implemented in the learning process, especially mathematics, showed that the post-test score was greater than the pre-test, where the pre-test score was (54.82), and the post-test score was bigger (81.02). The development of this animation learning media has made a positive contribution to the world of education because the challenges faced by teachers and students are quite heavy, especially in the learning process using information technology.

\section{ACKNOWLEDGMENTS}

Our gratitude goes to The Muhammadiyah University of Palangkaraya and the Institute for research and community service, who have supported lecturers in conducting research and publish reputed international journals.

\section{REFERENCES}

Alherz, A., Tsuruta, N., \& Kondo, K. (2020). Multiple-character animation systems for children at different educational stages. International Journal of Asis Digital Art \& Design, 1-7.

Alsubaie, S. S., \& Alabbad, A. M. (2020). The effect of japanese animation series on informal third language acquisition among arabic native speakers. English Language Teaching, 13(8), 91-119. https://doi.org/10.5539/elt.v13n8p91

Amri, I., Amiruddin, R., Palutturi, S., \& Mallongi, A. (2020). The Influence of Disaster Counseling with Animation Video on Preparednes Students in Elementary School in Palu. 1302-1306.

Andini, D., \& Supriadi, N. (2018). Media animasi menggunakan macromedia flash berbasis pemahaman konsep pokok bahasan persegi dan persegi panjang. Desimal: Jurnal Matematika, 1(2), 149. https://doi.org/10.24042/djm.v1i2.2278

Arslan, R., Kofoğlu, M., \& Dargut, C. (2020). Development of augmented reality application for biology education. Journal of Turkish Science Education, 17(1), 62-72. https://doi.org/10.36681/tused.2020.13

Atsani, rohmatun, N., Asrowi, \& Tr, M. (2020). The effectiveness of value clarification technique ( VCT ) and problem-based learning ( PBL ) models on social problemsolving skills viewed from emotional intelligence. Elementary Education Online, 19(20), 1751-1767. https://doi.org/10.17051/ilkonline.2020.734977

AYDIN G (2020). The effects of guided inquiry-based learning implementations on 4th grades students and elementary teacher; a case study. Ilkögrretim Online (elektronik), 
19(3), 1155 - 1184. Doi: doi:10.17051/ilkonline.2020.727298 Azhar, A. (2017). Media Pembelajaran. Rajawali Pers.

Dewi, N. R., Magfiroh, L., Nurkhalisa, S., \& Dwijayanti, I. (2019). The development of contextual-based science digital storytelling teaching materials to improve students' critical thinking on classification theme. Journal of Turkish Science Education, 16(3), 364-378. https://doi.org/10.12973/tused.10288a

Fatmawati, K., Arief, Y. S., \& Kurnia, I. D. (2020). The effect of animation video modeling on mother' $\mathrm{s}$ ability in preparing toilet training in toddler. EurAsian Journal of BioSciences, 1581(July 2019), 1575-1581.

Fauzy, R., \& Revita, I. (2020). “ MUHSIN AND MAHASIN ” AND ITS IMPLEMENTATION IN EDUCATION AND TEACHING. 5(1). https://doi.org/10.22216/jcc.2020.v5i1.4150

Fujiawati, F. S. (2016). Pemahaman konsep kurikulum dan pembelajaran dengan peta konsep bagi mahasiswa pendidikan seni. Jurnal Pendidikan Dan Kajian Seni, l(1), 1628.

Handayani, S., Haryono, H., \& Ahmadi, F. (2020). The effectiveness of animation film media to know ability mathematical concept of early childhood based on gender. Journal of Primary Education, 9(2), 161-167. https://doi.org/10.15294/jpe.v9i2.36493

Hanif M. (2020). The Development and effectiveness of motion graphic animation videos to improve primary school students' sciences learning outcomes. International Journal of Instruction.; 13 (3): 247-266. DOI: 10.29333/iji.2020.13416a 13(3).

Haviz, M., Maris, I. M., Adripen, Lufri, David, \& Fudholi, A. (2020). Assessing preservice teachers' perception on 21 st century skills in Indonesia. Journal of Turkish Science Education, 17(3), 351-363. https://doi.org/10.36681/tused.2020.32

Leasa, M., Corebima, A. D., \& Batlolona, J. R. (2020). The effect of learning styles on the critical thinking skills in natural science learning of elementary school students. Elementary Education Online, 19(4), 2086-2097. https://doi.org/10.17051/ilkonline.2020.763449

Nainggolan, B., Hutabarat, W., Situmorang, M., \& Sitorus, M. (2020). Developing innovative chemistry laboratory workbook integrated with project-based learning and character-based chemistry. International Journal of Instruction, 13(3), 895-908. https://doi.org/10.29333/iji.2020.13359a

Nasir, M. (2018). Design and development of physics learning media of three dimensional animation using blender applications on atomic core material. .JOURNAL OF EDUCATIONAL SCIENCES, 2(2), 23-32.

Neta, F., Yulius, R., Fajri, M., \& Nasrullah, A. (2020). Effectiveness of Using 2D Animation Video with Live Shoot Motion Graphic. 423(Imc 2019), 119-127.

Ngurah, G., Pramana, Y., Sudana, O., Made, G., \& Sasmita, A. (2020). 3D animation 
learning media regarding the teachings of kanda pat sari. Journal of Education and Practice, 4(3), 1-5.

Reilly, P. (2020). The development of student motivation to learn english at a university in Mexico. International Journal of Instruction, 13(3), 401-416. https://doi.org/10.29333/iji.2020.13328a

Sarioğlu, S., \& GIrgIn, S. (2020). The effect of using virtual reality in 6th grade science course the cell topic on students' academic achievements and attitudes towards the course. Journal of Turkish Science Education, 17(1), 109-125. https://doi.org/10.36681/tused.2020.16

Shah Bani, S., \& Mohamad Nordin, N. (2020). Using youtube as learning tool for children: a case study of kuntum animation youtube channel. Asian Journal Of Research In Education And Social Sciences, 2(2), 43-53. Retrieved from http://myjms.mohe.gov.my/index.php/ajress/article/view/9603

Siburian, S., Hutagalung, S. M., \& Daulay, S. (2020). Development of adobe flash cs6 learning media in short story- based on learning text of advanced local community of batak toba students in Tanjungmorawa. BirLE-Journal, 3(1), 591-599. https://doi.org/https://doi.org/10.33258/birle.v3i1.855 591

Şılbır, L., Coşar, A. M., Kartal, Y., Altun, T., Atasoy, M., \& Özçamkan-Ayaz, G. (2020). The graphic symbol-based interactive animation development process for deaf or hard-of-hearing students. International Electronic Journal of Elementary Education, 12(4), 371-382. Retrieved from https://www.iejee.com/index.php/IEJEE/article/view/973

Sofyan, H., Hartati, S., Anggereini, E., Muazzomi, N., \& Ramadhan, S. (2020). Developing e-module local wisdom based for learning at kindergarten In Jambi, Indonesia. Ilkogretim Online - Elementary Education Online, 19(4), 2074-2085. https://doi.org/10.17051/ilkonline.2020.763331

Sukmana, J. (2018). Metode 2D hybrid animaton dalam pembuatan film animasi di macromedia flash mx. Pseudocode, 5(1), 29-36. https://doi.org/10.33369/pseudocode.5.1.29-36

Suratno, Bevo, W., Chen-Yen, C., Arini, R., \& Yushardi. (2020). Exploring a direct relationship between students' problem - solving abilities and academic achievement: A STEM education at a coffee plantation area. TÜRK FEN E ĞITIMI DERGISI, 17(2), 211-224. https://doi.org/10.36681/tused.2020.22

Tafonao, T. (2018). Peranan media pembelajaran dalam meningkatkan minat belajar mahasiswa. Jurnal Komunikasi 103. https://doi.org/10.32585/jkp.v2i2.113

Utomo, A. P., Lutfiah, H., Erlia, N., Suratno, \& Nurul, U. (2020). The effectiveness of STEAM-Based biotechnology module equipped with flash animation for biology learning in high school. International Journal of Instruction, 13(2), 463-476. 
https://doi.org/https://doi.org/10.29333/iji.2020.13232a

Wiyarsi, A. (2020). Vocational high school students ' chemic al literacy on contextbased learning : a case of petroleum topic. Journal of Turkish Science Education, 17(1). https://doi.org/10.36681/tused.2020.18

Yusuf, I., Widyaningsih, S. W., \& Sebayang, S. R. B. (2018). Implementation of Elearning based-STEM on quantum physics subject to student HOTS ability. Journal of Turkish Science Education, 15(Special Issue), 67-75. https://doi.org/10.12973/tused.10258a 